\title{
AWOISM AND THE UNENDING SEARCH FOR TRANSFORMATIONAL LEADERSHIP IN NIGERIA: POLITICAL, ECONOMIC, EDUCATIONAL AND SOCIAL CHALLENGES
}

\author{
Aare Afe Babalola* \\ DOI: https://dx.doi.org/10.4314/jsdlp.v10i1.7
}

\section{INTRODUCTION}

I consider it an exceptionally great honour for me to receive the 2018 Chief Obafemi Awólowo prize for leadership. I thank the Governing Council and Board of Trustees of the Foundation for finding me worthy of this monumental honour, and for the privilege to join the two eminent past recipients of this Award, namely, Professor Wole Soyinka in 2012 and Thabo Mbeki in 2014.

It is one of the greatest joys of my life that I am associated with an award named after an accomplished leader of men, iconic pan-Africanist, resolute nationalist, astute administrator, consummate family man, preeminent statesman, bridge builder, revered leader of the Yoruba people, Nigeria's foremost federalist, one of the greatest African leaders of all time, and an epitome of the good life, Chief Jeremiah Oyeniyi Obafemi Awolowo, GCFR.

In my heart, there is no question of my pleasure and pride in receiving the prestigious award. However, I am at the same time very mindful of the high moral duties and responsibilities that such an award brings to its recipients. It is a direct call to reflect upon, and exemplify, the virtues and principles of good governance, selflessness, public spiritedness and transformational leadership which Chief Awolowo exhibited and championed all through his life on this planet. Chief Awolowo was a political institution and innovator, who made the impossible possible. His people-centred ideals and policies: free

* Text of a keynote lecture delivered on 6 March 2019 by the 2018 Recipient of the prestigious Chief Obafemi Awolowo Prize for Leadership, Aare Afe Babalola, OFR, CON, SAN, LL.D (Lond.), FNAILS, FNSE FCI.Arb, President Emeritus and Founder, Afe Babalola University, Ado Ekiti. 
education, free healthcare, economic empowerment, first television station in Africa; the Liberty Stadium, Cocoa House, public welfare, ethnic tolerance and national pride were all very expensive and impossible at that time, given that there was no oil and gas windfall at the time, and were financed by income from agriculture. They were, however, made to look easy and possible by Chief Awolowo's careful and meticulous planning. This doggedness and determination of making the impossible possible is the hallmark of Awoism.

\subsection{Transformational Leadership versus Transactional Leadership}

Since Nigeria and Africa lost the visionary leader, many self-proclaimed Awoists have emerged, whose actions and priorities outrightly negate the people-centred ideals and philosophy of Awoism. Rather than offer transformational leadership to the Nigerian people, we have witnessed the rise of transactional leaders who view leadership from the narrow lens of self-aggrandizement, self-interest, short-termism and the suppression of the public will. Some of our leaders have simply become our greatest hazard as a nation.

The present system and government encourage politicians to do everything and anything to attain power. The politicians see the attainment of power not as a means to an end but as the end in itself. They will bribe, corrupt, intimidate, coarse, browbeat and indeed resort to every trick in the book to be a Senator, Rep member, Governor, Minister, Commissioner, Local Government Chairman, Member of the House of Assembly and even Local Government Councilor. This has a direct effect on the quality of leadership available to the country. On their part, members of the electorate, many of whom have been affected by the downturn in the economy of the country, are easily bought over with the huge resources available to the corrupt politicians.

\subsection{Many Rulers but Few Leaders}

On the contrary, the old Western Region under Chief Awolowo had a higher standard of living than most Western democracies at the time. Today, Nigeria is the poverty capital of the world. Some 87 million Nigerians (about half of our population) currently live in extreme poverty. Also, according to UN estimates, extreme poverty in Nigeria is growing by six people every minute. Life expectancy in Nigeria today is about 48 years, which is lamentable when compared to United States (79 
years), Canada (82 years), Switzerland (83 years) and even Ghana (63 years). The Nigerian nation has lost its direction and focus, and has become a state with many rulers and a few leaders. For many years, the prosperity, peace and progress of the Nigerian nation have been held hostage by a clique of kleptocratic rulers who make the possible impossible, and make the impossible unattainable. Thirty-two years after Chief Awolowo's transition, the search for transformational leadership across Nigeria's political, economic, social and educational sectors remains complex, desperate and incomplete.

Distinguished ladies and gentlemen, Nigeria can witness peace, progress and prosperity again, if our political class fully understands and implements the political philosophy and postulations of Chief Awolowo on political, economic, social and educational governance. My remarks today will, therefore, reflect on the tenets and political, economic and educational ideology of Awoism and how they remain indispensable if Nigeria is to address the structural imperfections and deformities in our political, economic, social and educational systems.

\section{AWOISM AS A POLITICAL IDEOLOGY: TRUE FEDERALISM, REGIONAL AUTONOMY AND MULTICULTURALISIM}

Awoism, as a political philosophy, puts a premium on true federalism, regional autonomy and multiculturalism. His book, Path to Nigerian Freedom (which I will rebrand as Oath to the Nigerian Nation) - the first federalist manifesto by any Nigerian politician - expertly advocated federalism as the only basis to safeguard the interests of the over 250 diverse ethnic nationalities that make up Nigeria. Given the size and diversity of a heterogeneous nation like Nigeria, Chief Awolowo foresaw that it would be impossible for a central government to effectively finance and oversee all key sectors of the economy. Furthermore, he understood that Central, Eastern, Northern and Western Regions of Nigeria had divergent cultures and belief systems; different religions; distinct languages; and most importantly dissimilar interest in formal education. While the Western Region believed very strongly in formal education, the North believed more in pastoralism, agriculture and informal and largely Islamic education; while the East was the home of industrialists and tradesmen. Thus, at the end of the amalgamation in 1914, even the colonial authorities struggled to understand a functional and coherent structural direction to which the new Nigerian 
state should evolve. Studies show that the official records of Mr A. J. Harding, a clerk in the Colonial Office, after reading through Luggard's proposal for the amalgamation of 1914, concluded that the emergent state would be "impossible to classify". He warned that:

... it is not a unitary state with local government areas but a central executive and legislature. It is not a federal state with federal executive, legislative and finances, in addition to provincial executive, legislatures and finances. It is not a personal union of separate colonies under the same Governor. It is not a confederation of states. If adopted, his proposal can hardly be a permanent solution.

With one man in practical control of the executive and legislative organs of all the parts, the machine may work possibly for sufficient time to enable the transition period to be left behind, by which time the answer to the problem - unitary state or federal - would probably have become clear. ${ }^{1}$

Mr Harding further described Lord Luggard's amalgamation idea as an "unauthorized scheme", and recommended breaking the country into four provinces, namely the Central, Eastern, Northern and Western provinces. ${ }^{2}$ Perhaps this was why our first national anthem cautiously acknowledged that "though tribes and tongue may differ, in brotherhood we stand."

Chief Awolowo was an unrepentant federalist. As the leader of the Action Group, he presented clear and compelling proposals for a federal constitution in the constitutional conferences held in London preindependence. He had a vision for equal power and resource sharing arrangement between the central government and the federating units. As he famously noted in his book, Thoughts on the Nigerian Constitution:

If a country is unilingual or bilingual or multilingual, and also consists of communities which over periods of years have developed divergent nationalities, the constitution must be federal and the constituent states must be organized on the dual basis of language

1 Emphasis added. Public Records Office, Colonial Office, London, Vol. 583. Amalgamation Reports.

2 See The Foundations of Nigeria: Essays in Honour of Toyin Falola, p. 187; also B.I.C. Ijomah: Nigerian Nationalism and the Problems of Integration, (Oluluben Publishers, 2011, p. 20). 
and nationality $\ldots$ any experiment with a unitary constitution in a bilingual or multilingual country must fail in the long run... since Nigeria is a multilingual and multinational country par excellence, the only Constitution that is suitable for its peculiar circumstances is a Federal Constitution. ${ }^{3}$

Some of these ideals were reflected in the 1954 Lyttleton Constitution which recognized the autonomy of each region with each region having its own legislative and executive powers. The 1960 Independence Constitution, as well as the 1963 Republic Constitution, retained the federal structure with each region remaining semiautonomous and self-governing.

However, the unfortunate incursion of the military into the Nigerian political space led to a gradual annihilation of the tenets of true federalism in Nigeria. With military leadership came the absolute concentration of powers in the central government. The military constitutions, among other things, accumulated several executive powers to the central government, thereby strangulating the capacity of the regions and states to independently finance and execute development programmes.

\subsection{The 1999 Constitution}

These relics of military rule are unfortunately still present today. For example, it is beyond comprehension that 20 years after Nigeria returned to democratic governance in 1999, we have retained the 1999 military Constitution as our supreme law. The 1999 constitution continues to limit the capabilities of states and local governments to sustain developmental initiatives and projects. The current situation whereby state governments have to go to Abuja every month with the begging bowl for federal allocations is an aberration that explains the poor state of Nigeria's federalism today. We have gradually replaced the derivation formula and the tenets of true federalism, with an allocation formula that is only imaginable under a unitary state. The Western Region is the worst victim of the Unitary Constitution which has affected education, health and economic development. Virtually all the educational, economic and agricultural programmes put in place by Chief Awolowo had collapsed.

3 Obafemi Awolowo, Thoughts on Nigerian Constitution (Ibadan: Oxford University Press, 1966), pp. 12-22. 
In a truly federal constitution, provinces or states have the constitutional authority to control resources derived from their territories. Fiscal federalism, as a tenet of federalism, dictates equitable sharing of expenditure and fiscal instrument among the central, states and local tiers of government. Under a truly federalist state, fiscal autonomy and responsibility are granted to subnational governments, with state and local governments having adequate resources to perform their functions autonomously, such that no tier is subservient to the other.

In Canada, for example, oil and gas resources are owned and controlled by the provinces. Section 109 of Canada's Constitution Act, 1867 explicitly vests ownership rights to all lands, mines, minerals and royalties for oil and gas resources to the provinces in which they are derived. ${ }^{4}$ The oil-rich province of Alberta, for example, retains its oil wealth and pays a predetermined amount of contribution to the federal government. This is in far contrast to the current situation in Nigeria where the federal government exercises ownership rights and control over oil and gas resources found in different states, and in the reverse pays allocation to oil and gas owning states. This warped model of federalism serves as disincentives to states and local governments to develop other forms of resources in their territories. For example, under Chief Awolowo, the Western Region had a functional economy based primarily on cocoa farming and exports. Recognizing the fiscal autonomy of states and local governments will go a long way to boost innovation and spur investment in other key sectors such as agriculture.

The uneven allocation of powers and responsibility between federal, state and local governments is at the heart of the ongoing agitation for a restructuring of the Nigerian federation. Although federalism has no universally applicable template, as it is a context-specific notion that must be driven by the political and structural realities of every country. However, there are few common characteristics that are basic and fundamental to a true federation, the most important of which is an equal distribution or allocation of powers, such that each unit has ultimate sovereignty, with none preeminent over or subordinate to the other. ${ }^{5}$ While the federal government is to have power over matters that are of general interest to the nation, states and local governments

4 See Andreì Plourde, "Oil and Gas in the Canadian Federation".

5 Ronald Watts, Administration in Federal System (London: Hutchinson Educational, 1971), p. 8. 
in a federalist nation ought to have powers over matters that are peculiar to their local communities. In the exercise of their powers, all tiers must retain substantial autonomy on a wide range of subjects, to enable them run their governments and manage their affairs. As summed up by Eso JSC in Nkwocha v. Governor of Anambra State "the bedrock of federalism lies in each tier of government being a master in its own domain." 6

This is the kind of reform and restructuring that we need in Nigeria. Our current claim to being a federation is not only comical and deceitful, it indeed requires urgent surgical operation. Restructuring is not a call for disunity or conflict, it is a well-informed call for a speedy return to the confederation principles contained in the independence Constitution which our regional leaders negotiated with the British between 1957 and 1959. The earlier we restructure the country to revert to true federalism, the sooner we can begin to witness economic recovery. Fiscal federalism and financial autonomy will go a long way to address some of the perennial agitations and crises, such as the Niger-Delta crises and threats of secession by various ethnic groups, that have remained insurmountable for decades. Without urgent and true restructuring, Nigeria's search for peace, security and progress may remain elusive.

\subsection{Economic ideology of Awoism}

Awoism as an economic ideology envisions a progressive welfare state, centred around the empowerment, social welfare and freedom of the people. Chief Awolowo pioneered Africa's brand of the British philosopher, John Locke's liberal political philosophy, that is based on liberty and equality and in which the welfare of the people is the supreme law (Salus populi suprema lex). Awoism doggedly recognizes the welfare of the people as the very essence of government and governance.

An Awoist state is one in which everyone acquires primary and secondary education for free; where citizens would enjoy free health care; access to world-class state-led infrastructure; have gainful employment; and in which basic needs are met by a functional and efficient public service. At considerable expense, Chief Awolowo introduced free primary education for all, which in its first year alone

6 (2001) F. W. L.R 48 at 1410. 
in 1954, registered 394,000 pupils. He established the first television service in Africa, constructed the Liberty Stadium amongst other social welfare projects that in no time transformed the Southwest into an infrastructural paradise.

\subsection{Employment: The Best Cure for Poverty}

Chief Awolowo's investment in agriculture also provided gainful employment for the citizens. Prior to the commercial discovery of oil in 1956, Nigeria was renowned for its prowess in agriculture, ranging from the towering groundnut pyramids in Kano in Northern Nigeria, to palm oil in the Eastern parts and the cocoa revolution in Chief Awolowo's Western Region. Chief Awolowo launched farm settlement schemes under the Economic Project Performance Unit (EPPU), the forerunner of Odua Investment Company Limited, which provided finance and land for large-scale agricultural projects in the region. The Apoje and Lomiro oil palm, as well as rubber and cocoa plantations in Ilushin and Ikenne, among other agricultural projects, provided significant revenue for the government, cheaper food commodities and gainful employment for citizens, as well as raw materials for manufacturers. They also served as laboratories for students in agricultural courses and institutions to acquire practical skills.

Awoism recognizes the importance of agriculture and economic diversification as an essential pillar for providing a decent standard of living, providing food and freedom from poverty to the citizens. It is propelled by the simple Yoruba adage that "if hunger is removed from poverty, then poverty becomes insignificant." Also, the Yoruba adage that "employment is the best cure for poverty" is a crucial foundation of Awoism. Awoism reckons that all human beings need a certain amount of economic power for them to be patriotic and honourable. As the leading scholar Rhonda Howard once propounded:

a man's belly must be full before he can indulge in the luxury of worrying about his political rights and freedom. ${ }^{7}$

Also, Mahatma Ghandi, the father of the Indian independence movement, also famously remarked: "there are people in the world so

7 R. Howard, "The Full Belly Thesis: Should Economic Rights Take Priority over Civil and Political Rights? Evidence from Sub-Saharan Africa" (1983) 5 Human Rights Quarterly, p.469. 
hungry, that God cannot appear to them except in the form of bread..." What do we have today? Following the advent of oil and gas exploration in Nigeria, agriculture and farming progressively took a back seat in Nigeria. Nigeria has over the last two decades functioned primarily as a monoculture in which about 80 per cent of government income, 90-95 per cent of export earnings and more than 90 per cent of foreign exchange revenues in Nigeria are all derived from the oil sector. Furthermore, emphasis on agricultural training, research and capacity building waned significantly with agricultural careers becoming less preferred among Nigerian graduates and youths. The result is the near annihilation of the agricultural sector of the Nigerian economy and a sharp rise in endemic poverty, hunger and starvation across Nigeria.

Failure of successive governments in Nigeria to sustain agricultural expansion, economic emancipation and liberty of the Nigerian people is closely intertwined with the rise of instability, insecurity and violence in the country. The most unsafe countries on earth are home to a significant concentration of the poorest and hungriest people. For example, sub-Saharan Africa is home to most of the most dangerous cities in the world which are found in Somalia, Libya, Democratic Republic of Congo and sadly Nigeria. For the 10th successive year, Nigeria is ranked in the top 20 of the most dangerous countries on earth. Poverty in Nigeria has bred desperation, which has in turn entrenched chaos, insecurity and anarchy. Nigeria's poorest are hungry, angry and desperate; and have easily embraced thuggery, militancy and terrorism.

On the other hand, the most peaceful countries on earth are the richest countries in terms of economic opportunities and welfare. Canada, Iceland, Norway, New Zealand, Austria, Portugal, Denmark and Qatar are ranked as some of the most peaceful countries in the world. Similarly, for the 10th successive year, Europe remained ranked as the most peaceful geographical region in the world. These statistics show a direct correlation between economic emancipation and national security. With Nigeria being recently ranked as the poverty capital of

8. Quoted in The Statement by Ambassador H.E. Remigio Martin Maradona, Director General \& Head of IIMSAM Observer Delegation to the United Nations Economic and Social Council http://iimsam.org/en/wp-content/uploads/2014/05/ OFFICIAL-STATEMENT-OF-DG-ON-UN-WORLD-FOOD-DAY-16-OCT-08.pdf. 
the world, the country is on the dangerous path of becoming crowned soon as the crime capital of the world unless something drastic is done to liberate our people from poverty.

This is a principal reason why I have consistently advocated for the respect, protection and fulfilment of the people's right to a decent standard of living in this country. A decent standard of living goes beyond the current clamour of a minimum wage. What the people of Nigeria deserve is a living wage that can guarantee their liberty and economic prosperity. For many years, the Nigerian people have endured economic captivity in the hands of the political class, who will rather distribute garri, rice and vegetable oil to them during elections, rather than provide them with a living wage. Nigeria has one of the lowest minimum wages in the world. The recently celebrated minimum wage of N30,000 (US\$98) is pitiable when compared to those of other countries: Luxembourg (US\$2,100), Netherland (US\$1,780), Ireland (US $\$ 1,800$ ), Belgium (US $\$ 1,500$ ), France (US\$1,700) and South Africa (US\$250). All these dwarf the minimum wage that the Nigerian government approved recently.

As a practising lawyer, I have, for many years, advocated that a living-wage is not a privilege or philanthropic gift from government. Rather, it is a fundamental right of every citizen of this country. Article 11 of the International Covenant on Economic, Social and Cultural Rights expressly recognizes the "right of everyone to an adequate standard of living for himself and his family, including adequate food, clothing and housing, and to the continuous improvement of living conditions." Similarly, Article 25 of the 1948 Universal Declaration of Human Rights recognizes the right of every person to an adequate standard of living. Article 23 also provides that everyone has the right to work, to free choice of employment, to just and favourable conditions of work and to protection against unemployment. These international human rights instruments require countries to take positive measures to prevent unemployment, underemployment, including removing as far as possible, all causes of poverty.

Despite being a party to many of these core international human rights instruments, Nigeria has perennially failed to respect, protect and fulfil the rights of its citizens to an adequate standard of living. Unfortunately, these basic internationally recognized rights are hidden away in the nonjusticiable section of the Nigerian Constitution. The current constitution, fostered on Nigerians by the military in 1999, unscrupulously placed the economic prosperity under Chapter II called: 
the Fundamental Objectives and Directive Principles of State Policy. This portion of the Constitution indeed graciously and rightly provides that

The State shall direct its policy towards ensuring: suitable and adequate shelter, suitable and adequate food, reasonable national minimum living wage, old age care and pensions, and unemployment, sick benefits and welfare of the disabled are provided for all citizens. ${ }^{9}$

While these are good and robust provisions, section 6, sub-section (6), paragraph (c) of the same Constitution however provides that the judiciary shall have no powers to decide on any issue or question as to whether any act of omission by any authority or person is in conformity with the Fundamental Objectives and Directive Principles of State Policy. This provision makes it difficult, if not impossible, for citizens to sue the government for failing to provide them free education, jobs, food, shelter and security. In essence, like a greek gift, the constitution in one breadth contains wishful aspirations or dreams about economic prosperity, and in another breath takes it away from the citizens. There is an urgent need to modify these archaic provisions and recognize the rights of the Nigerian people to a decent standard of living as an important and enforceable fundamental human right. By so doing, the Nigerian people will have a robust legal basis to demand for an enforcement of their rights to welfare in courts, rather than resorting to strikes and protests.

The Nigeria of my dream is one in which the fundamental rights of all citizens to a decent standard of living, food, security, health, education, work, and well-being are respected, protected and fulfilled to the fullest extent.

\subsection{The Educational Ideology of Awoism}

It is a notorious fact that Chief Awolowo was a singular arrowhead and defender of the rights of the Nigerian people to qualitative education. In addition to providing free primary education in the Western Region, Chief Awolowo was instrumental to the establishment of the University of Ife (now rightly known as Obafemi Awolowo University [OAU]). His vision for OAU was to promote quality

91999 Constitution of the Federal Republic of Nigeria, Cap 23 LFN 2004. 
University education, character development and spartan self-discipline. As the respected Sage once noted:

Any system of education, which does not help a man to have a healthy and sound body, alert brain, and balanced and disciplined instinctive urges, is both misconceived and dangerous. ${ }^{10}$

He also remarked that:

Any people that is starved with books, especially the right type of books, will suffer intellectual malnutrition, stagnation and atrophy. ${ }^{11}$

These lofty ideals and visions of the founding father of OAU, which is to reform and promote qualitative education in Nigeria, are strikingly the same visions and ideals that I have passionately championed and dedicated my entire life to. Like Chief Awolowo, I work tirelessly to be, and will hope to be remembered as, a staunch proponent of University reform in Nigeria; and an ardent defender of the rights of the Nigerian people to qualitative, affordable, and accessible education.

For many years, Nigerian Universities have at a geometric rate waned in quality, substance and prestige. Nigerians who taught or attended any Nigerian university between 1965 and 1990 would easily appreciate the extent of annihilation and dilapidation of necessary physical structures and facilities in many of our universities. A combination of infrastructural decay, lack of adequate funding, dearth of qualitative practical training curriculum and inability to attract the best teaching minds have all stagnated our Universities to the current appalling point whereby QS World University Ranking and other global rankings that rank Universities based on facilities, programme and instructional content, perennially fail to rank or mention a single Nigerian university in the top 1,600 category. For many of us, this situation was an unbearable dishonour to the legacy of Chief Awolowo that required urgent and aggressive turnaround.

It was the commitment to play a role in reforming Nigerian educational system that spurred me to initiate diverse reform programmes during my tenure as the Pro-Chancellor and Chairman,

10 Obafemi Awolowo, The People's Republic (Ibadan: Oxford University Press, 1968).

11 Ibid. 
Governing Council of the University of Lagos. Many of the achievements we recorded during that period have been lauded globally and remain a reference point till today, including being adjudged twice as the best Pro-Chancellor in Nigeria.

\subsection{Establishment Afe Babalola University, Ado-Ekiti (ABUAD)}

This same vision led me to establish Afe Babalola University in 2009. Since 2009, ABUAD has grown astronomically in reputation and has won several national and international awards and recognition as the fastest-growing University in Africa and as a shining beacon of University education in Nigeria. The reforms we embarked on at ABUAD cut across curriculum development, practice-based learning, funding, teaching, research and entrepreneurial and vocational skills. Consequently, in just eight years of its existence, ABUAD has been recognized by the Nigeria Universities Commission (NUC) as "a model, benchmark and reference point for other universities" and also as "the pride of University education in the country".

In a personality lecture in honour of our fathers, our role models, foremost educationist, courageous nationalist and great Nigerians delivered by Professor I. A. Olaoye, Professor of History and International Studies and Director, Centre for Archives and Documentation, University of Ilorin, the Professor acknowledged the immense contribution of Chief Obafemi Awolowo Foundation, when he said:

One cardinal philosophy of the Obafemi Awolowo Foundation is to preserve and nurture the legacy of education of the late sage to fruition. In this regard, the hope of a rewarding education system in future is not lost. In the same vein, the gigantic stride of our father and mentor, Chief Aare Afe Babalola, in the establishment of Afe Babalola University, Ado-Ekiti, is an indication that there will be light at the end of the tunnel. Although, I have not been to the University, but what I have been seeing on the television and reading from the newspapers are symptomatic of "Renaissance" that promises the re-birth of [a] glorious period of education in Nigeria.

Let me state here that based on their vision for education and general development of Nigeria, the late Chief Obafemi Awolowo and Aare Afe Babalola, and a few others like them, have always been seen 
by most of us to be in the mould of Nationalists and Pan-Africanists such as Herbert Macaulay, Nnamdi Azikwe, Kwame Nkrumah, Leopold Sedar Senghor, Houphouet Boigny, Dauda Jawara, Gnassingbe Eyadema, Marcus Garvey, E.W. Blyden and W.B. Dubois to list but a few. In point of truth, Aare Afe Babalola, just like the late sage, is strongly passionate about how to reform our education system in Nigeria. His popular column on Thursdays in the Nigerian Tribune has always addressed a variety of issues on education such as the need for quality education, good remuneration for teachers, review of the school curriculum and education which is responsive to the needs of the country. His strong passion for the future of education in Nigeria is not misguided, knowing him as a foremost educationist and erudite lawyer (SAN) and someone who hails from the home of Professors, Ekiti-Kete

Ladies and gentlemen, the hope of a rewarding education system in Nigeria is not lost. My personal commitment and aspiration is to do all that is humanly possible, to make the Nigerian university system the best in the world. I am very confident that we will get there. I perceive education as the full development of the human mind, cutting across cognitive, affective and psychological domains. Education goes beyond schooling; it transcends classroom teaching. It is the process of inviting truth and acquiring all-round knowledge, skills, values, beliefs, and character, needed to become a better citizen.

Quality education throughout life is the birthright of every human being on earth. The right to education is one of the most basic rights recognized in international law and in the laws of every civilized country of the world. Education has long been recognized as both a human right and an indispensable means of realizing other human rights. Education is also a principal tool for unlocking prosperity and eradicating endemic poverty. According to the United Nations, every year of formal education increases an individual's earning capacity by up to 10 per cent. The higher the level of education, the greater the chance of escaping poverty.

\subsection{Passport to the Future}

Education is undoubtedly the passport to the future; each page is filled with limitless opportunities. Standing before you today is a living example of the transformative power of education. This is why that Chinese adage states "If you are planning for a year, sow rice; if you are planning for a decade, plant trees; if you are planning for a lifetime, educate people." Investment in education is the only sure way to the 
liberation of human minds. As I tell my students, education, especially quality education, breeds discipline, discipline breeds character, character breeds hope, and hope never fails.

Given the intrinsic value of education to human life, the environment, prosperity and survival in general, international law has emphasized the right of every individual on earth to quality education. As far back as 1948, Article 26 of the Universal Declaration of Human Rights proclaimed that:

Everyone has the right to education. Education shall be free, at least in the elementary and fundamental stages. Elementary education shall be compulsory. Technical and professional education shall be made generally available and higher education shall be equally accessible to all on the basis of merit. Education shall be directed to the full development of the human personality and to the strengthening of respect for human rights and fundamental freedoms...Parents have a prior right to choose the kind of education that shall be given to their children. ${ }^{12}$

The key elements in this Declaration are accessible, available, affordable and quality education. In 1989, the United Nations Convention on the Rights of the Child, in Articles 28 and 29, stipulated that primary education should be "compulsory and available free to all". Article 13 of the International Covenant on Economic, Social and Cultural Rights (ICESCR) also recognizes the right of everyone to free primary school education and the obligation of governments across the world to progressively introduce "free education for secondary and higher levels". Articles 13.3 and 13.4 also require countries to respect the educational freedom of parents by allowing them to choose private educational institutions for their children. These instruments emphasize the need for free education even at higher levels such as the University.

\subsection{Budget for Education}

Although the UNESCO High-Level Group on Education for All has recommended that every country should spend no less than 15-20 per cent of yearly budgets on education, a spending threshold of 30 per cent of the yearly national budget on education has been recommended

12 Emphasis added. See Universal Declaration of Human Rights, adopted 10 Dec.1948, G.A Res.217A9 (III), 3 UN GAOR, UN Doc. A/810 at 71 (1948). 
as necessary for African countries to catch up and address the current infrastructure deficits. Unfortunately, however, despite perennial rhetoric by successive Nigerian governments on their plans to build world-class universities, many have consistently failed to meet the UNESCO funding benchmark. For example, in Nigeria, the 2017 budget N448.01billion was allocated to education, representing only about 6 per cent of the N7.30 trillion budget. As a signatory to these important international law instruments, Nigeria has a fundamental obligation, as a responsible nation, to fully respect, protect and fulfil the right to education of every citizen, in accordance with the provisions of international law.

\section{PATHWAYS TO TRANSFORMATIONAL LEADERSHIP IN NIGERIA}

Several years after the titanic strides of Chief Awolowo, the search for transformational leadership in Nigeria remains ongoing. In this final part of my address, I will propose how true national leaders in the mould of Chief Awolowo can emerge and how Nigeria, a country of many nations, can metamorphose into a nation properly so-called and how we can move closer to the ideals of Awoism.

\subsection{Full Restructuring: A Necessity for the Emergence of the Nigerian Nation}

The founding fathers of Nigeria agreed on true federalism in Lancaster House in London between 1950 and 1960 having taken into consideration the differences in culture, religion, philosophy of life, attitude to work, languages and so on. One who believes that his father is a fool would sooner than later regret his own foolishness. There is an urgent need for total devolution of powers to enable each state or geo-political zone to effectively administer its resources and sociopolitical needs. The federal government should only be concerned with the management of common political affairs like currency, foreign affairs, etc. with this political recipe, there will be less crisis and quarrel or inordinate ambition to become president, minister or legislator. As a matter of fact, the late Sardauna Amadu Bello found regional premiership more prestigious than being the Federal Prime Minister. 


\subsection{Qualification and Remuneration for Political Officer Holders}

Political offices in this country have been made too attractive with each state spending a huge percentage of government revenue on salaries and allowances. Yet there are 36 Houses of Assembly, two national Legislative Houses, an array of Commissioners and Ministers. In addition, they maintain a large number of aides and assistants at public expense. We also have a large number of Special Assistants, Senior Special Assistants, Private Secretaries. If we have all these for the elected, we also have them for the unelected. For instance, the First Lady has an array of assistants. At the local government level, we have the Chairmen and a large number of officers. Politics in Nigeria today is viewed primarily as a business and not as a means of service to the nation. In the First Republic masterminded by Chief Awolowo, members of the House of Assembly did not earn salaries; they were paid sitting allowances. More importantly, legislative business was parttime.

Furthermore, there has to be a change to the qualifications for seeking political office. Rather than have a minimum educational qualification of Senior Secondary School or WAEC, it should be a first degree with a minimum of second class lower. Such person must also be self-employed or have viable means of self-sustenance prior to seeking political office. They must also have held positions of responsibilities. The position of Local Government Councillors should be reserved for retired and highly experienced people like teachers, professors, other professionals and clergymen who also must serve on part-time basis with payment of sitting allowances only.

\subsection{Agriculture}

As stated earlier, Agriculture was the mainstay of the economy of this country in the First Republic. The fact remains that agriculture is the major employer of labour all over the world. However, in Nigeria, agriculture is virtually abandoned. In the court of law, particularly in election petition cases when witnesses are asked what is their occupation, the answer invariably is "politics". Our government has been paying lip service to agriculture by urging people to go back to farm. I do not know a father who will tell his son who has just graduated to return to the farm and use cutlass and hoe. Agriculture is an attractive business if we adopt mechanized farming as is done in other countries. 
I am confident that our youths can go back to the farms if the government can make available agricultural equipment to all local governments which can be hired by the youths. All they need to do is pledge their farmland as security.

If soft loans at the rate of 2-3 per cent are made available to youths, most of the young graduates will certainly want to go back to farming.

Generally, to revive the lost glory of agriculture in Nigeria, I suggest that:

a. Agricultural science must be taught in elementary and secondary schools as a compulsory subject

b. All universities must encourage students to study agriculture by reducing school fees such as exemplified by my university ABUAD where tuition is reduced to 50 per cent. In addition, the government should emulate how ABUAD empowers graduates in agriculture with N250,000 as an initial start-up on their farms.

Finally, each family throughout this country should be encouraged to come together and merge their smallholdings for the purpose of large-scale farming.

\subsection{Education}

I have addressed the issue of poor funding in education over the years. I will recommend once more that this country must comply and implement UNESCO recommendation and budget 26 per cent for the maintenance of education annually. The fact must be told that our universities simply do not have the financial wherewithal to compete with other universities around the world. Most advanced countries appreciate that government alone, having regard to its responsibilities on infrastructure, cannot provide a quality education that will accommodate all applicants seeking admission to the university. That is why, in addition to providing robust financial support for public universities, special financing should be set aside to support the establishment of private universities that can bridge the gap of insufficient space for interested and qualified university candidates. The government must encourage and appreciate individuals who have the means and interest in education. This is why, on this occasion, I once more thank the Awolowo Foundation for appreciating what I am doing in education. 
Again, the government should set up more scholarships and avenues for students to obtain loans to finance their education.

In this respect, I wish to appeal to the government to bring back the Education Bank established by virtue of the Nigerian Education Bank Act. Cap N104, Laws of the Federation of Nigeria 2010. This bank was empowered by law to approve and disburse loans to students to finance their education in institutions of higher learning. Regrettably, that bank has folded up.

\section{A SINGLE SIX-YEAR TENURE FOR PRESIDENT AND GOVERNORS}

The Constitution of the Federal Republic of Nigeria 1999 (as Amended) limits the period which any individual can serve as President of the Federal Republic of Nigeria to two terms of four years each.

It is not in dispute that the just concluded elections at the State and Federal levels generated immense interest and palpable tension in the country and consumed an unimaginable amount of money. Many governors right from the date of their swearing-in began planning for their re-election. As the period for the selection of candidates by political parties as stipulated by the Electoral Act drew nearer activities in several states came to a halt as many state functionaries, including commissioners and ministers became engrossed in issues pertaining to the elections. Members of the National Assembly were at a point all busy in their respective constituencies scheming to retain the tickets of their parties forgetting their constitutional duties of lawmaking. The result is that important matters which require attention are always left unattended to.

Thus, ministers who should daily supervise the implementation of important government policies were busy running campaigns. As a matter of fact, contractors and judgment debtors, including millions of dollars due to my clients, were not paid even though payment had been approved by the Senate.

During his first media chat, former President Goodluck Jonathan GCFR proposed a single term of six years on the grounds that re-election activities cause a lot of unnecessary distraction. In his words:

Every four years you conduct elections, you create so much tension in the political environment. As we are talking, some people are busy holding meetings for the 2015 elections. It creates [a] series 
of confusion in the political environment. I am not saying that single tenure, alone, will bring one hundred per cent stability. There is no political system that is one hundred per cent stable, you must have some tension. That was why I came up with that. ${ }^{13}$

Whilst the comments of the former President attracted a lot of debate with some attributing it to a desire for tenure elongation events continue to show that there is a need for an urgent re-appraisal of the current two terms of four years for the President and State Governors.

I, therefore, believe that the two-term limits provided in the Constitution need urgent reappraisal. According to the French political thinker, Alexis de Tocqueville, "The desire to be re-elected is the chief aim of the President; that the whole policy of his administration, and even his most indifferent measures, tend to this object."

A single 6-year term will certainly pave way for the emergence of transformational leadership. In Nigeria, the preparation for the second term has made our election campaign a do-or-die affair with tragic consequences, including assaults, killings, burning of electoral materials, thuggery, malpractices, bribery and corruption, etc.

\section{LEADERSHIP AND DISCIPLINE}

I must now address a critically important requirement which is mandatorily relevant to transformational leadership. Those of us who had the privilege of observing Chief Awolowo at work recalled with relish that Awoism is synonymous with discipline. Chief Awolowo was a highly disciplined man; very selfless, timeous, God-fearing, respectful, humble but firm, skilful, focused, loving, honourable, enterprising and presentable. Please ask yourself, how many of us have these attributes? Regrettably, the youths of today are worse than the elders. Perhaps this is due to the curriculum in public schools and universities where morals are relegated to the background. Apart from ABUAD and some mission-based private universities, discipline is virtually non-existent in our universities. The three pillars on which ABUAD is built are determination, industry and discipline. This is strictly observed by students and teachers and defaulters are sanctioned.

13 See "Senate Recommends Inclusion of 6-Year Single Term for President, Governors in New Constitution" (30 April 2013) https://newsbytesnow. wordpress.com/2013/04/30/flash-senate-recommends-inclusion-of-6-yearsingle-term-for-president-governors-in-new-constitution/. 
While the older generations may find it difficult to change their habit, it is possible that the new generation of youths can be made to imbibe the philosophy of Awosim and the characteristics of an ideal leader. We all speak about change in our attitude both to politics and work. The older generation, like a cast iron, may find it difficult to imbibe the philosophy of Awoism, but the younger ones can. To illustrate how apostles of Awoism can emerge, I wish to quote from a letter written to me by an alumnus of my university (ABUAD), Popoola Olamide, who won the Unilever World Competition in London in 2016. Part of the letter reads:

... Sir, in one of your speeches, you mentioned that you had the urge to make a difference in the world and that drove you to build a world-class university. The truth is that you have not just made a difference; you're building a new world. If you only wanted to make a difference according to the world's definition, you could have instead invested your time and resources to build an empire of big businesses ranging from oil to banking. Or you could have decided to invest in politics, with the quality of your integrity and wisdom you would have been such a great leader the nation will not forget soon.

... But sir, you chose not to make a mere difference in the world, but rather you decided to build a new world, a new Nigeria. You decided to set the foundation for a new kind of people, you decided to invest in the younger generation, to give your time and effort in exchange for a brighter tomorrow. And you, knowing that the only sustainable change is the change that changes the mind, built an institution that will construct the minds of the youths; all these in exchange for nothing.

Truth be told, you are a blessing to the world. Your dedication to humanity is like no other; even the Queen had to honour you because, in reality, no one can overlook your contributions. You have sponsored the fatherless, you have fought for the weak and powerless, and, more importantly, you are always in the habit of building leaders and making everyone better. I am so proud I met you, I am glad that I had the opportunity to be mentored by you. Every time you say to us, "you will be greater than me", we wonder in our minds "how possible is that?", but then you have taught us just how to go about it, you have planted yourself in each and every one of us. Now we can reproduce you in every area of life. 
Some of us might not know it now, but they will come to appreciate you someday soon.

In less than nine years, I succeeded in building a new generation of people, a new crop of decent Nigerians who believe in the tenets of ABUAD Ideology - Industry, Determination and Discipline. It, therefore, follows that those who believe in Awoism and practise the tenets of Awoism religiously can emerge as transformational leaders like Chief Awolowo.

\section{CONCLUSION}

In conclusion, it is evident that a ruinous combination of lack of true federalism, lack of sustained government investment in education, abandonment of agriculture by successive governments, indiscipline, inadequate emphasis on morals in our institutions, poor leadership, Godfatherism, conversion of politics into business enterprise and the huge salaries and allowances paid to political office holders and the two terms for Governors and President have, over several decades, rendered the search for transformational leadership in Nigeria illusory and utopian.

All hope is however not lost. All of us, leaders and followers in the Nigerian project have pivotal, sacred and indispensable roles to play in contributing our strategic opinions and efforts to reversing the current trend. As John Galbraith, an economist and public intellectual, once noted:

... All of the great leaders have had one characteristic in common: it was the willingness to confront unequivocally the major problems of their people in their time. This, and not much else, is the essence of leadership. ${ }^{14}$

Chief Obafemi Awolowo tackled the wicked challenges of his time with great vigour, intellect and selflessness, and history will forever remain kind to him.

Looking around this room today, I can see his proud and worthy children, grandchildren and great-grandchildren, the highly dedicated

14 See Mark Latham, A Conga Line of Suckholes: Mark Latham's Book of Quotations (Melbourne University Press, 2006) 105. 
editorial board of the ageless Tribune newspaper which continues to educate Nigerians on Awo's thought weekly, leaders of Yoruba race who are believers in Awoism, the members of Nigerian Bar Association, members of Emmanuel Chambers, ABUAD staff and all other admirers and well-wishers of Chief Obafemi Awolowo. I thank all of you for your patriotism. Like Awo, let us tackle the complex challenges facing our country today. I very much look forward to working with you all to make it happen.

Ladies and Gentlemen, I thank you once again for this prestigious award and for your patience. 